\title{
Selection of autolytic lactic acid bacteria as potential adjunct cultures to accelerate ripening of white-brined cheeses
}

\section{Selime Hazır Dalca', Ömer Şimşek ${ }^{1 *}$, Oguz Gursoy², Yusuf Yilmaz ${ }^{2}$}

\author{
'Pamukkale University, Department of Food Engineering, TR-20017, Denizli, Turkey \\ ${ }^{2}$ Burdur Mehmet Akif Ersoy University, Department of Food Engineering, TR-15030 Burdur, Turkey \\ ${ }^{*}$ Corresponding author/Dopisni autor: Tel: +90 258 2963015; E-mail: omers@pau.edu.tr
}

\section{Abstract}

The aim of this study was to select lactic acid bacteria (LAB) having autolytic activity on the basis of the technological aspects to accelerate the ripening of white-brined cheeses. For this purpose, mesophilic $(n=526)$ and thermophilic $(n=413)$ LAB isolates were collected from 34 raw milk and 16 cheese samples. 27 LAB isolates with a high autolytic activity ranging from 34 to $54 \%$ were identified by (GTG) fingerprint and 16S rDNA sequence analyses, which showed that Lactococcus lactis and Enterococcus faecium were abundant among the autolytic isolates in raw milk while E. faecium and Lactobacillus casei were in white-brined cheese. The autolysis rate of LAB strains increased by raising the temperature and $\mathrm{pH}$; however, decreased somewhat at high $\mathrm{NaCl}$ concentrations. Additionally, the highest autolysis was observed in the presence of glucose for most of the strains. On the other hand, Lb. plantarum PFC231 was autolyzed differently, being the highest in the presence of lactose. E. durans PFC235, E. faecium PFC232 and Lb. plantarum PFC231 were autolyzed more than other LAB strains, when exposed to low $\mathrm{pH}$, high $\mathrm{NaCl}$ concentration at $10^{\circ} \mathrm{C}$ simultaneously. However, only Lb. plantarum PFC231, Leuconostoc mesenteroides PFC234, Lc. lactis subsp. cremoris PFC233, Pediococcus acidilactici PFC237 and Lb. rhamnosus PFC238 were able to show intracellular caseinolytic activity. In conclusion, Lb. plantarum PFC231 has the potential to be used as an adjunct starter culture in the production of white-brined cheeses because of its autolysis at low temperature, $\mathrm{pH}$ and high salt concentrations, as well as intracellular caseinolytic activity.

\section{Key words: lactic acid bacteria, Lactobacillus plantarum, autolysis, white-brined cheese, cheese ripening}

\section{Introduction}

The main function of lactic acid bacteria (LAB) used as starters in fermented foods is to produce lactic acid to give the characteristic nature of foods. However, various physiological behaviors of $L A B$ can also provide desirable characteristics in fermented food products (De Vuyst and Leroy, 2007). For instance, LAB strains contribute to the development of desired flavor aroma in cheese by autolysis during ripening (McSweeney, 2004; Hannon et al., 2007). In this process, peptides are cleaved into smaller units and free amino acids by intracellular peptidases released during $L A B$ autoly- 
sis. Thereby aromatic precursors such as branchedchain and sulfur-containing amino acids responsible for the formation of volatile aroma compounds are substantially released (Beresford et al., 2001). Activity of lipolytic enzymes, which are hydrolases that cleave the ester linkage between a fatty acid and the glycerol core of the triacylglyceride, is also crucial for flavor development in some cheese varieties (Collins et al., 2003).

Autolysis is the enzymatic cleavage of cell wall peptidoglycans by peptidoglycan hydrolases present in bacterial cells called autolysin. In fact, bacterial peptidoglycan hydrolases act in different cellular functions that are necessary for the modification of the rigid peptidoglycan network during the cell growth and division. It also allows for the elimination of weakened or impaired cells in the cell population (Shockman et al., 1996). Peptidoglycan hydrolases with different specificity and/or structure may be present in a bacterial cell at the same time and these relevant hydrolases constitute a complex enzymatic system (Chapot-Chartier and Kulakauskas, 2014).

LAB may exhibit autolytic activity at different levels depending on the cell wall composition, the presence of autolysis-stimulating conditions and genomic defects (Lortal and Chapot-Chartier, 2005). Apart from these, differences in peptidoglycan structure during cell division can alter the autolysis behavior of the same species (Smith et al., 2000). The level of LAB autolysis is dependent on factors such as carbon source, temperature, osmotic concentration, growth phase and $\mathrm{pH}$, and the autolytic activity of LAB may change from 32 to $94 \%$ (Dako et al., 1995; Lortal and Chapot-Chartier, 2005; Boutrou et al., 1998; Cıbık and Chabot-Chartier, 2004).

Autolytic $L A B$ have been isolated to improve the aroma properties of various cheeses (Collins et al., 2003; Lortal and Chapot-Chartier, 2005; Lazzi et al., 2016; Meng et al., 2018). However, to the best of our knowledge, the isolation of autolytic $L A B$ with a potential for accelerating the ripening of white-brined cheeses has not been studied yet. White-brined (or pickled) cheeses are ripened and stored in brine, and produced worldwide under various names and by different processing methods. Bovine or mixtures of other milk types can be used at different ratios in the production (Gursoy et al., 2013). Some of the white-brined cheeses are pro- duced with pasteurized milk, and cheese blocks are ripened in brine (3 to $15 \% \mathrm{NaCl}$ ) up to 6 months. In the traditional production of white-brined cheeses, raw milk is used without any lactic culture; however, in modern dairy plants, commercial lactic cultures have been used (Gursoy et al., 2013). Cheese ripening is influenced by various factors including the endogenous and exogenous enzymes and microflora derived from the raw milk, starter cultures, coagulants, manufacturing and ripening conditions (Fox and McSweeney, 1996; Sousa et al., 2001; Wilkinson and Kilcawley 2005). Proteolysis is usually regarded as the main biochemical process during cheese ripening and one of the most important factors for the development of typical cheese flavor and texture. However, high salt concentration and acidic conditions cause long ripening of white cheese.

In this study, LAB with high autolytic activity were selected on the basis of the technological aspects of white-brined cheese ripening. The potential of $L A B$ with both autolytic and intracellular caseinolytic activities as an adjunct starter culture was determined in white-brined cheese production.

\section{Materials and methods}

\section{Materials}

In this present study, raw milk ( $\mathrm{n}=34)$ and whitebrined cheese samples $(n=16)$ produced without any starter culture were collected from local farms, producers and open markets of Denizli (Turkey) and used for the isolation of autolytic $\mathrm{LAB}$. Isolates were stored at $-20^{\circ} \mathrm{C}$ in culture medium containing glycerol (20\%) throughout the study.

Isolation, identification and determination of autolytic activity of LAB

Isolates were collected on MRS and M17 agars supplemented with $0.5 \%$ glucose, which were incubated at $43{ }^{\circ} \mathrm{C}$ (thermophilic) and $30^{\circ} \mathrm{C}$ (mesophilic) under aerobic conditions that were seeded from appropriate dilutions prepared from the obtained raw milk and cheese samples.

Prior to the identification of collected isolates, autolytic activities were determined according to Çıbık and Chapot-Chartier, (2004). Accordingly, the optical density (OD) of each isolate at $620 \mathrm{~nm}$ 
was adjusted to a value between 0.6 to 0.8 with potassium phosphate buffer (100 mM, pH 7.0), and changes in optical density at $30{ }^{\circ} \mathrm{C}$ monitored for 24 hours. Autolysis rates of the isolates were calculated by the following equation. $\mathrm{x} 100]$

Autolysis Rate $(\%)=100-\left[\left(\mathrm{OD}_{\text {final }} / \mathrm{OD}_{\text {initial }}\right)\right.$

To amplify (GTG) repetitive regions on the genomes of the isolates, master mix $(4 \mu \mathrm{L})$ (FIREPOL/ SOLIS BioDyne), primer (5-GTGGTGGTGGTGGTG-3) $(1 \mu \mathrm{L})$ and template DNA $(1 \mu \mathrm{L})$ were used in a PCR reaction of $20 \mu \mathrm{L}$. In the $\mathrm{PCR}, 95^{\circ} \mathrm{C} / 3 \mathrm{~min}$ initial denaturation, 30 cycles of $95{ }^{\circ} \mathrm{C} / 1 \mathrm{~min}, 45$ ${ }^{\circ} \mathrm{C} / 30 \mathrm{~s}, 72{ }^{\circ} \mathrm{C} / 5$ min reactions were applied and finalized with $72^{\circ} \mathrm{C} / 10 \mathrm{~min}$ final extension.

For the identification of the isolates, $1464 \mathrm{bp}$ of the 165 rDNA gene was amplified by PCR using two different primer pairs (529F-1491R and 27F-780R). PCR mixture was prepared with $5 \mu \mathrm{L}$ buffer, $2 \mu \mathrm{L}$ dNTP mix (Fermentas, Massachusetts, USA), $1 \mu \mathrm{L}$ each forward and reverse primer (529F 5'GTGCCAGCMGCCGCGG 3'-1491R 5 'ACGGCTACCTTGTTACGACTT 3' and 27F 5'AGAGTTTGATCCTGGCTCAG 3'-780R 5'TACCAGGGTATCTAATCCTGTT 3') 1 $\mu \mathrm{L} \mathrm{Hi}-\mathrm{Fi}$ Taq DNA polymerase (Fermentas, Massachusetts, USA) and $2 \mu \mathrm{L}$ genomic DNA, and total volume was completed to $50 \mu \mathrm{L}$. An amplification program was applied including initial denaturation at $95^{\circ} \mathrm{C} / 5 \mathrm{~min}, 30$ cycles of $95^{\circ} \mathrm{C} / 30 \mathrm{~s}$ denaturation, $57^{\circ} \mathrm{C} / 30 \mathrm{~s}$ annealing, $72^{\circ} \mathrm{C} / 1$ min extension and $72^{\circ} \mathrm{C} / 5$ min final extension in the PCR equipment (Techne, Staffordshire, UK). The 165 rDNA fragments were DNA sequenced which was subsequently searched for ultimate identification at BLAST (https://blast.ncbi.nlm.nih.gov/).

\section{Effect of environmental factors on autolytic activity of LAB}

To determine the autolytic activity of the LAB strains under different conditions such as $\mathrm{pH}$, salt concentration, incubation time, temperature and the presence of sugar, each $L A B$ strains, which were initially collected at $6000 \mathrm{~g}$ for $15 \mathrm{~min}$ after grown in MRS and M17G, were suspended to an OD value between 0.6-0.8 by using either potassium phosphate-buffered saline (PBS) $(100 \mathrm{mM})$ with a pH adjusted by $0.1 \mathrm{~N} \mathrm{HCl}$ to 3.5, 4.0, 5.0 and 7.0 or PBS (100 mM, pH 7.0) containing 3.0, 5.0, 7.0 and $10.0 \% \mathrm{NaCl}$. Autolytic activity was deter- mined after incubation at $30{ }^{\circ} \mathrm{C}$ for $24 \mathrm{~h}$. In another group, $L A B$ isolates were suspended in PBS (100 mM, pH 7.0) to an OD value between 0.6-0.8 and kept at 10, 20, 30 and $40{ }^{\circ} \mathrm{C}$ followed by the determination of autolytic activity after 12 and 24 hours. To determine the effect of a carbon source used in growth medium on autolysis, LAB strains were first cultivated in modified MRS and M17 media containing $1 \%$ either glucose, lactose, sucrose or maltose, then centrifuged and re-suspended in PBS buffer (100 mM, pH 7.0). Autolysis percentages were determined at $30^{\circ} \mathrm{C}$ after $24 \mathrm{~h}$. To determine the combined effect of the relevant factors on autolysis, cells were suspended in four different PBS buffers (100 mM) with a pH adjusted to 4 or 5 and salt concentration of 3 or $5 \%$ to a final OD value between 0.6-0.8, and autolysis percentages were determined subsequently.

\section{Determination of intracellular proteolytic activity of LAB after autolysis}

The intracellular proteolytic activity of autolytic $\mathrm{LAB}$ was determined by screening the casein fragmentation by cellular enzymes released after autolysis. Accordingly, LAB cells were first adjusted to an OD value between 0.6-0.8 with PBS (100 mM, pH 7.0). Therefore, cells were allowed to autolyze at $30^{\circ} \mathrm{C}$ for $24 \mathrm{~h}$. Subsequently, cell debris was separated by centrifugation at $9000 \mathrm{~g}$ for $15 \mathrm{~min}$, and supernatant was filtered through a $0.45 \mu \mathrm{m}$ syringe filter. Casein mixture (Sigma, St. Louis, MO, USA, Product No: 22078) $(0.1 \%)$ was added to each filtered supernatant, and aliquots were taken after 4, 24, 48 and $72 \mathrm{~h}$.

The fragmentation of casein by the enzymes obtained after autolysis of the selected LAB strains was screened with the SDS-polyacrylamide gel electrophoresis (SDS-PAGE) performed on 8 and $12 \%$ slab gel according to Schägger and von Jagow (1987). Samples were run at $75 \mathrm{~V}$ at stack gel and $100 \mathrm{~V}$ for separating gel until the marker staining reached the end of gel. Afterwards, gel was stained with the $0.23 \%$ solution of Coomassie Blue R-250 for $90 \mathrm{~min}$, and de-stained in the methanol/acetic acid solution (5\% methanol, $7 \%$ acetic acid). Destained gels were scanned using the Scanexpress 12000 (Mustac, Germany). Casein (Sigma, St. Louis, MO, USA, Product No: 22078) was run on gel after treated as above in only PBS as control to compare. 


\section{Statistical analysis}

One-way ANOVA in the Minitab 14.0 package program (Minitab Inc., State College, PA, USA) were used to determine the effect of environmental factors on autolysis of LAB strains. Tukey's test was used as a post-ANOVA test to compare the significant differences among samples at $\mathrm{a}=0.05$ level.

\section{Results and discussion}

\section{Autolytic behavior of LAB isolates in} microflora of raw milk and white-brined cheese

In this study, 515 and 424 isolates were collected from 34 different raw milk and 16 cheeses, respectiveIy, among the colonies grown on the MRS and M17G agars at thermophilic and mesophilic conditions. Subsequently, the autolysis rates of all isolates (a total of 939) were determined every $6 \mathrm{~h}$ during $24 \mathrm{~h}$.
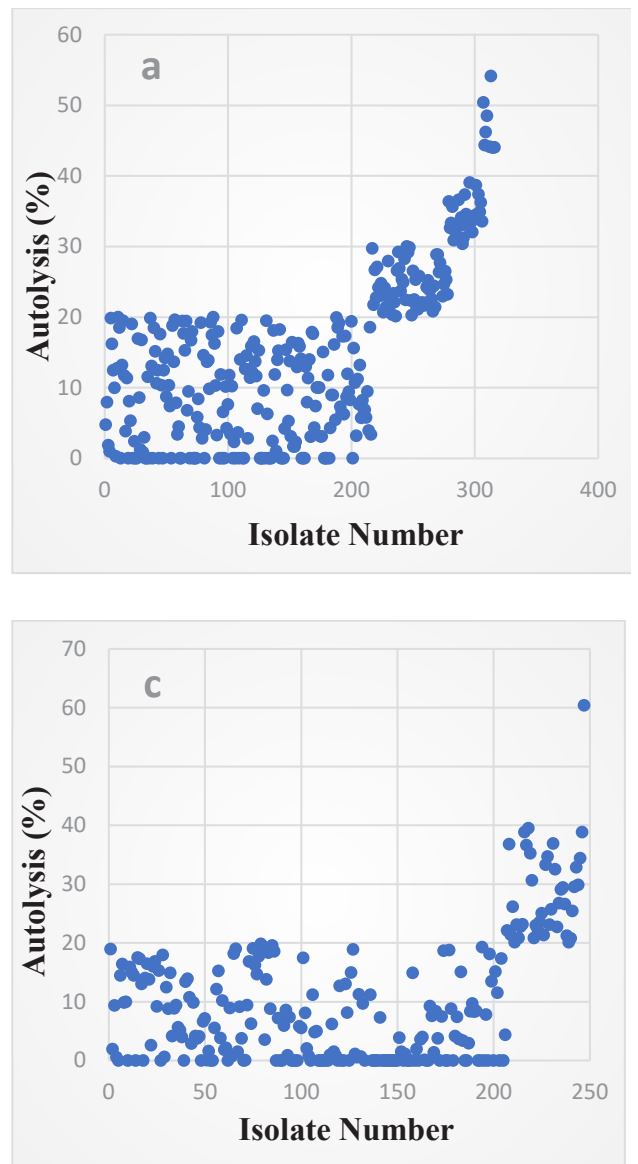

In terms of the distribution of autolysis rates of LAB isolates, $1.4 \%$ of the mesophilic isolates (1M11, 12M15, $19 \mathrm{M0} 04$ and 24M05) from raw milk showed an autolysis rate more than $50 \%$ while $12.3 \%$ of the isolates had an autolysis rate between 30 and $50 \%$ after $24 \mathrm{~h}$ (Figure 1a). Additionally, $2.6 \%$ of the thermophilic isolates (3T17, 5T08, 8T05, 11T13, 12 T08 and 17T17) autolyzed more than $40 \%$, and $27.7 \%$ of the isolates between 20 and $40 \%$ (Figure 1b). The autolysis rate was higher than $30 \%$ for $5.37 \%$ of the cheese mesophilic isolates (36M14, 42M07, 42M11, 42M13, 42M15, 42M19, 44M03, 47M01, 47M07, 47M09, 49M03, $50 \mathrm{MO} 8$ and $50 \mathrm{MO9}$ ), and $11.15 \%$ of the thermophilic isolates autolyzed 20 to $30 \%$ (Figure 1c). It was also found that $3.85 \%$ (45T20, 46T02, 46T04, 46T06, 46T20, 50T07 and 50TO9) of the thermophilic isolates had an autolysis rate more than $30 \%$, and $14.83 \%$ of the thermophilic isolates autolyzed 20 to $30 \%$ (Figure $1 \mathrm{~d}$ ).
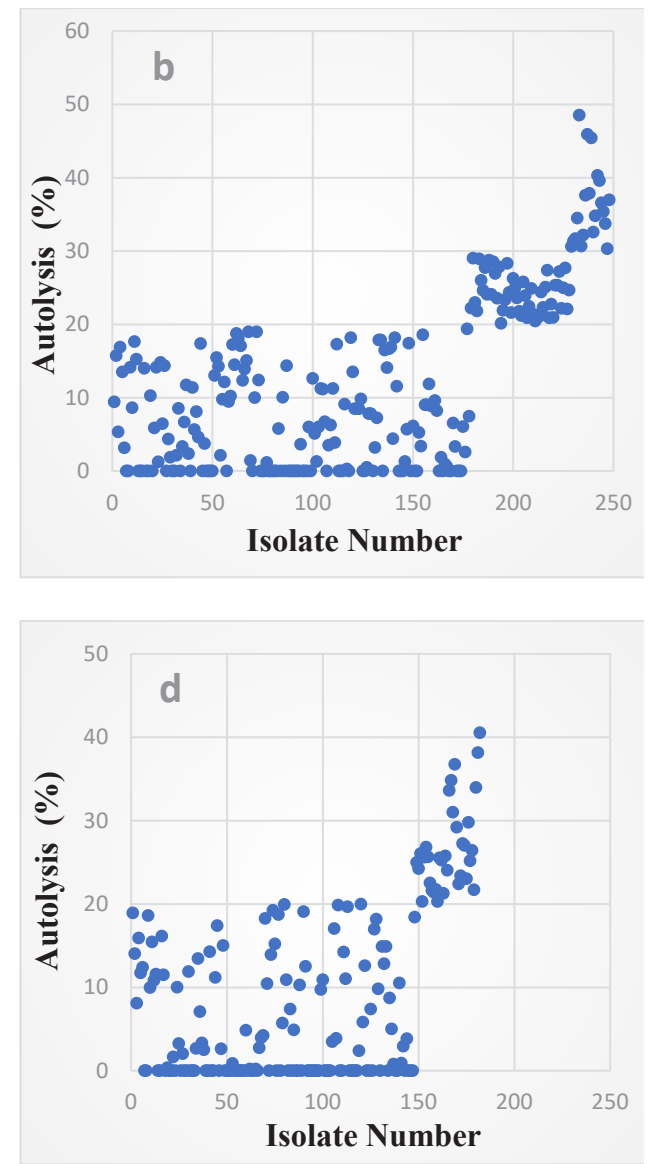

FIGURE 1. Distribution of autolysis rates as estimated at $30^{\circ} \mathrm{C}$ or $43{ }^{\circ} \mathrm{C}$ after $24 \mathrm{~h}$ incubation of cells in phosphate buffer ( $100 \mathrm{mM}$, $\mathrm{pH}=7.0$ ) for (a) mesophilic and (b) thermophilic isolates from raw milk and (c) mesophilic and (d) thermophilic isolates from whitebrined cheese samples 

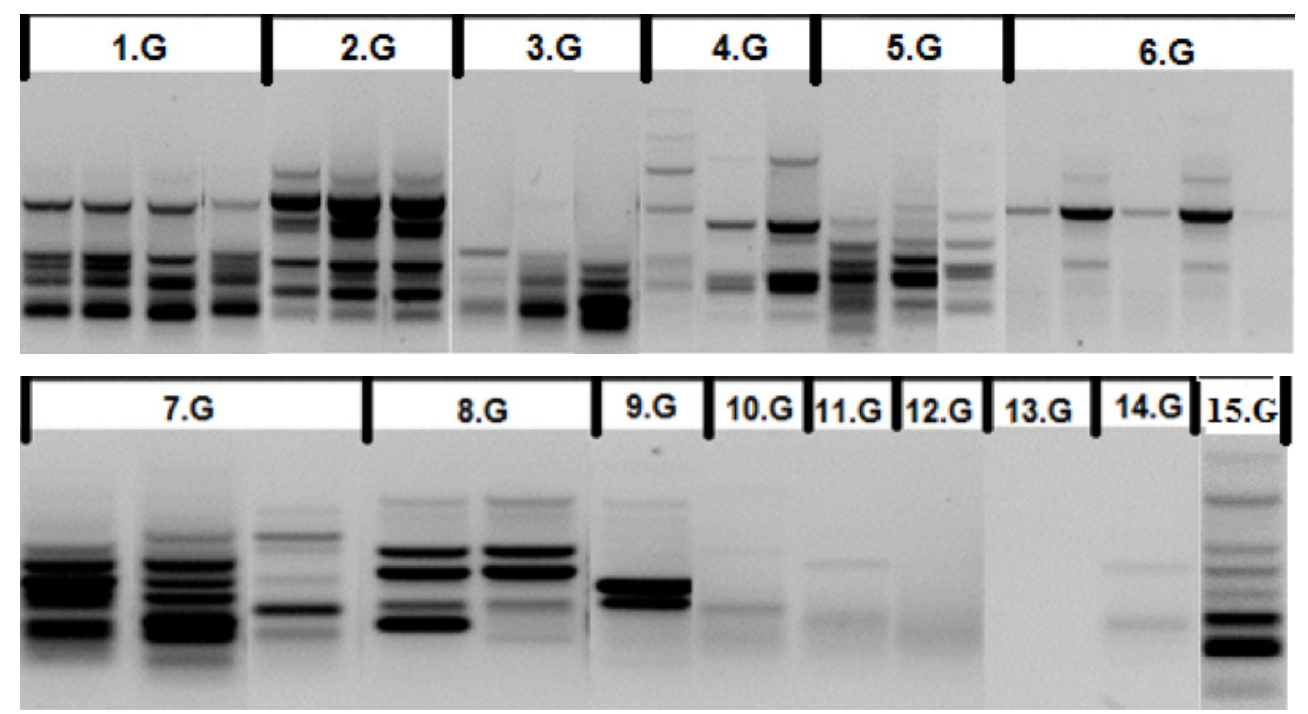

FIGURE 2. The (GTG) 5 profile of isolates with high autolytic activity obtained from raw milk and white-brined cheese samples

TABLE 1. Autolysis rates as estimated at $30^{\circ} \mathrm{C}$ (mesophilic, M) or $43^{\circ} \mathrm{C}$ (thermophilic, T) after $24 \mathrm{~h}$ incubation of cells in phosphate buffer (100 mM, pH=7.0) and homological characteristics of identified LAB isolates with high autolytic activity

\begin{tabular}{|c|c|c|c|c|c|}
\hline Source & Culture Code & Isolate Code* & Species** & Homology (\%) & Autolysis Rate $(\%)^{* * *}$ \\
\hline \multirow[t]{10}{*}{ Raw Milk } & PFC229 & $01 \mathrm{M09}$ & Lc. lactis subsp. lactis & 100 & 54.00 \\
\hline & PFC236 & 05T08 & Lb. helveticus & 100 & 48.85 \\
\hline & PFC235 & 03T17 & E. durans & 97 & 48.54 \\
\hline & PFC255 & $08 \mathrm{M} 13$ & Str. macedonicus & 98 & 44.10 \\
\hline & PFC234 & $10 \mathrm{M} 19$ & Leu. mesenteroides & 98 & 46.76 \\
\hline & PFC233 & $17 \mathrm{M} 20$ & Lc. lactis subsp. cremoris & 97 & 44.20 \\
\hline & PFC239 & $24 \mathrm{M08}$ & Lc. lactis subsp. lactis & 100 & 30.09 \\
\hline & PFC232 & $24 \mathrm{MO5}$ & E. faecium & 98 & 53.71 \\
\hline & PFC247 & $24 \mathrm{MO} 07$ & E. faecium & 99 & 39.45 \\
\hline & PFC254 & 19M02 & E. faecalis & 100 & 40.07 \\
\hline \multirow{17}{*}{$\begin{array}{l}\text { White- } \\
\text { Brined } \\
\text { Cheese }\end{array}$} & PFC240 & $42 \mathrm{MO}$ & Lb. casei & 100 & 38.87 \\
\hline & PFC241 & $42 \mathrm{M} 11$ & Lb. casei & 98 & 36.62 \\
\hline & PFc230 & $42 \mathrm{M} 13$ & Lb. casei & 100 & 39.50 \\
\hline & PFC242 & $42 M 15$ & Lb. casei & 99 & 35.22 \\
\hline & PFC243 & $42 M 19$ & Lb. casei & 99 & 30.64 \\
\hline & PFC249 & $45 T 20$ & E.faecium & 99 & 33.64 \\
\hline & PFC250 & 46T02 & E. faecium & 99 & 34.84 \\
\hline & PFC251 & 46T04 & E. faecium & 99 & 31.01 \\
\hline & PFC252 & 46T06 & E. faecium & 99 & 36.76 \\
\hline & PFC253 & $46 T 20$ & E. faecium & 99 & 40.53 \\
\hline & PFC244 & $49 \mathrm{MO3}$ & Lb. casei & 96 & 32.87 \\
\hline & PFC245 & 47M01 & Lb. plantarum & 97 & 34.69 \\
\hline & PFC231 & $47 \mathrm{MO}$ & Lb. plantarum & 97 & 36.88 \\
\hline & PFC246 & 47M09 & Lb. pentosus & 98 & 32.55 \\
\hline & PFC248 & $50 \mathrm{M08}$ & E. faecium & 98 & 38.83 \\
\hline & PFC237 & 50T07 & P. acidilactici & 99 & 33.99 \\
\hline & PFC238 & 50T09 & Lb. rhamnosus & 99 & 38.18 \\
\hline
\end{tabular}

${ }^{*} \mathrm{M}$ and $\mathrm{T}$ indicate mesophilic and thermophilic, respectively.

${ }^{* *} \mathrm{Lc}=$ Lactococcus, Lb = Lactobacillus, E = Enterococcus, Str = Streptococcus, Leu $=$ Leuconostoc, $\mathrm{P}=$ Pediococcus

*** rates in phosphate buffer $(100 \mathrm{mM})$ at $\mathrm{pH} 7.0$ 
Autolytic LAB diversity of raw milk and whitebrined cheese microflora

A total of $33 \mathrm{LAB}$ isolates selected from raw milk and cheese samples, which had autolysis rates more than $30 \%$, were ultimately identified. These isolates were clustered into 15 groups according to (GTG) ${ }_{5}$ profiles (Figure 2). Subsequently, two distinct regions of the $16 \mathrm{~S}$ rRNA gene overlapping each other were amplified for final identification of the selected 33 LAB isolates and therefore, DNA sequence of 1464 bp of 165 rDNA gene was taken into consideration. Accordingly, 27 isolates with high autolytic activity were $97 \%$ homolog with one LAB species (Table 1); however, remaining 6 isolates were not identified as $L A B$ species. Results indicated that Lc. lactis and E. faecium were abundance among the autolytic isolates in raw milk while E. faecium and Lb. casei were in white-brined cheese. The identification of E. faecium as high autolytic activity in both raw milk and white-brined cheese was in good agreement with microflora studies previously on these food samples. This is especially the case for Enterococcus spp., which can tolerate high salt concentrations (Amaral et al., 2017; Karabey et al., 2018). Recent studies have
A

B

C

D

FIGURE 3. Autolytic rates of $L A B$ strains at different growth conditions
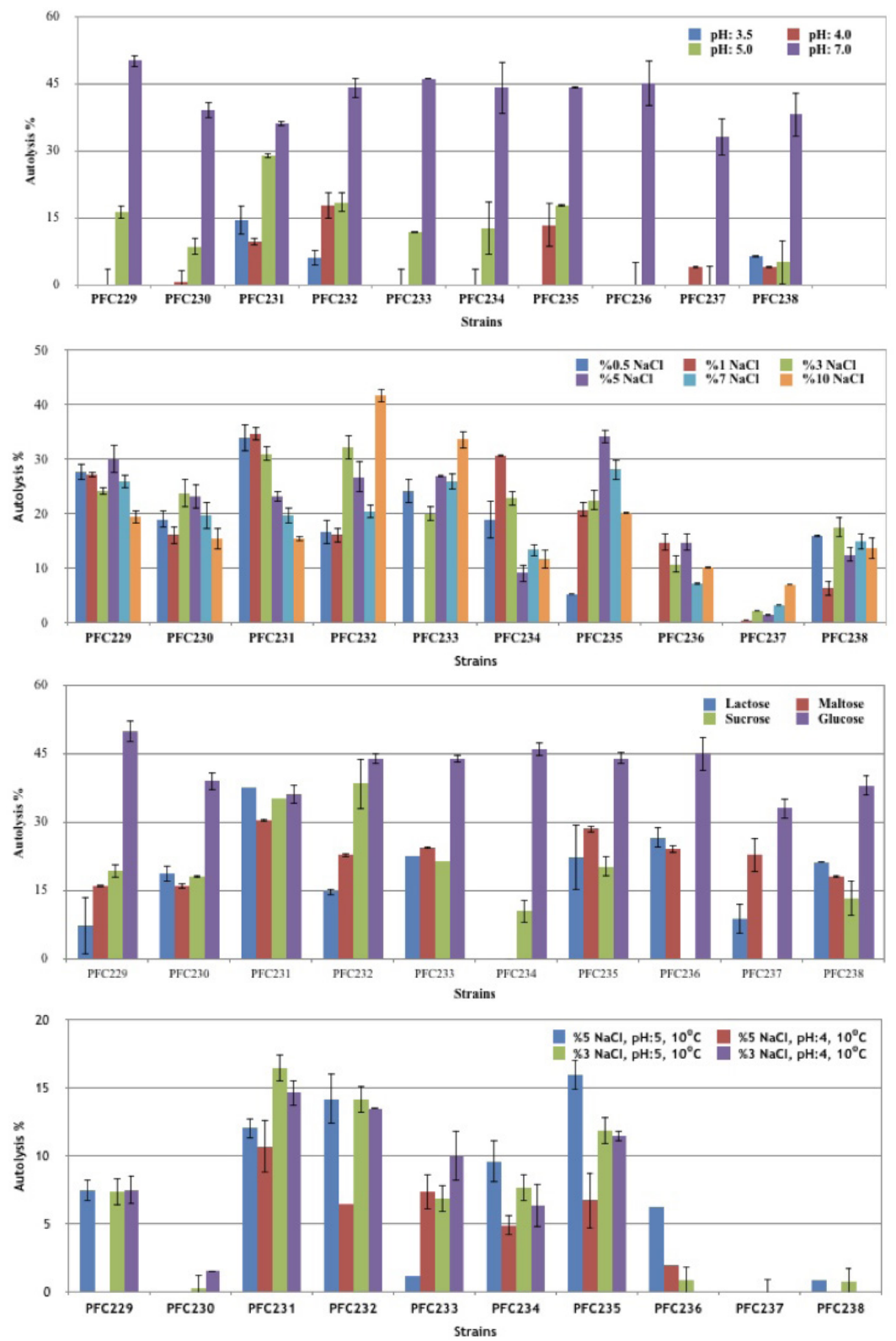
revealed that E. faecium has a potential as starter or adjunct culture in production of different cheese types (Ogier and Serror, 2008; Aspri et al., 2017). On the other hand, Lb. casei, Lb. plantarum and Lc. lactis subsp. lactis strains have been reported as
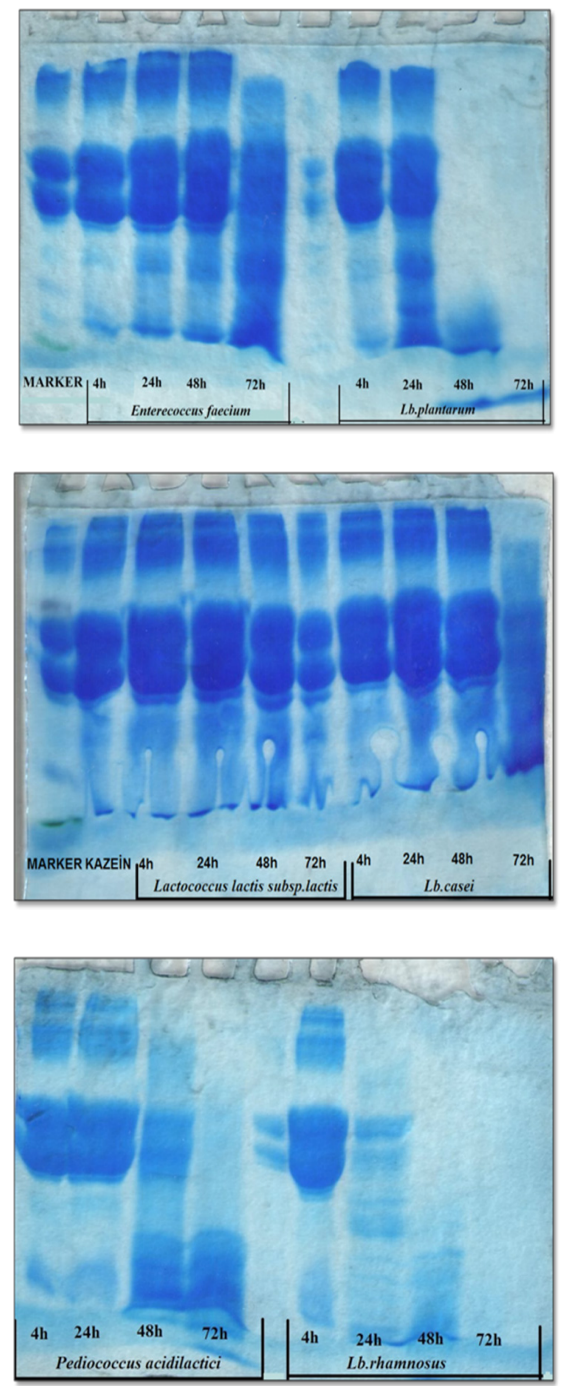

\section{Autolytic behavior of LAB strains under} different conditions

The effect of different $\mathrm{pH}$ values, salt concentrations and carbon sources on the autolytic behavior of 10 LAB strains was determined under conditions similar to the production of whitebrined cheese. The autolysis rates of $L A B$ strains decreased by a reduction in buffer $\mathrm{pH}$ as shown in Fig. 3a $(p<0.05)$. The LAB strains except $E$. faeci- predominant in terms of autolytic activity in many studies (Dako et al., 1995; Boutrou et al., 1998; Cıbık and Chapot-Chartier, 2004; Nunez et al., 2011; Piraino et al., 2008; Zuo et al., 2014).
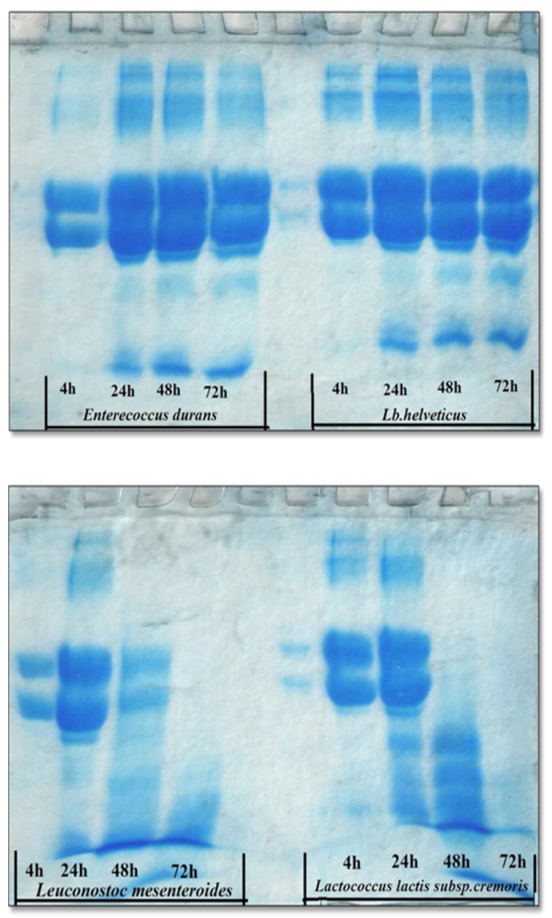

FIGURE 4. Intracellular caseinolytic activity of LAB strains after autolysis in $100 \mathrm{mM}$ potassium phosphate buffer $(\mathrm{pH}=7.0)$ at $30{ }^{\circ} \mathrm{C}$ for 4 to $72 \mathrm{~h}$ incubation as determined by SDS-PAGE analysis

um PFC232, E. durans PFC235 and Lb. rhamnosus PFC238 did not autolyze at pH values of 3.5 and 4. Significant reduction in the autolysis rates of $\mathrm{LAB}$ isolates associated with a $\mathrm{pH}$ drop might be related with the optimum $\mathrm{pH}$ required for the activity of peptidoglycan hydrolase (Chapot-Chartier and Kulakauskas, 2014). Similar results were reported by Ostlie et al. (1995), but Huard et al. (2004) and Nunez et al. (2011) reported that the autolysis rates increased with a decrease in $\mathrm{pH}$. 
Among LAB strains, Lb. plantarum PFC231, E. faecium PFC232, E. durans PFC235 and Lc. lactis subsp. lactis PFC229 were distinctive because of their high autolytic activity around pH 5.0, which was similar to that of white-brined cheese. The effect of $\mathrm{NaCl}$ concentration on autolysis behavior of $L A B$ strains was insignificant ( $p>0.05$ ). The maximum autolysis for each strain was found at a different $\mathrm{NaCl}$ concentration. Among all strains, the highest autolysis rate was determined in E. faecium PFC232 with $41 \%$ at a $\mathrm{NaCl}$ concentration of $10 \%$ (Fig. 3b). On the other hand, the autolysis rates of Lc. lactis subsp. lactis PFC229, Lb. casei PFC230 and Lb. plantarum PFC231 were not influenced by $\mathrm{NaCl}$ concentration ( $p>0.05$ ). Brine concentration of white-brined cheeses varies from 3 to $15 \%$, and autolytic characteristics of Lb. plantarum PFC231 (30-33 \%) and Lc. lactis subsp. lactis PFC229 (24-29\%) strains could be significant for the production of this type of cheeses. The autolytic activity of these strains was not influenced by $\mathrm{NaCl}$ concentration.

The highest autolytic activity was determined in growth medium with glucose, except for $L b$. plantarum PFC231 $(p<0.05)$ which was the highest (37\%) in the presence of lactose (Fig. 3c). Insignificant differences in autolysis rates were found for $L A B$ strains in growth media containing sugars other than glucose. Vegarud et al. (1983) noted that the use of glucose instead of lactose as a carbon source in growth medium promotes the development of autolysis. On the other hand, high autolytic activity of Lb. plantarum PFC231 in the presence of lactose may have a technological importance for white-brined cheese production in which lactose is the main carbon source for such strains.

Since starter cultures used in white-brined cheeses may encounter with low pH, high salt concentration and cold conditions during ripening, the simultaneous effect of these factors on the autolysis of LAB strains was also studied. High autolysis rates in 6 of $10 \mathrm{LAB}$ strains were observed in medium containing $5 \% \mathrm{NaCl}$ at pH 5 . In 3 of these ten strains, the highest autolysis rate was found in medium with $3 \% \mathrm{NaCl}$ at pH 4 (Fig. 3d). Lb. plantarum PFC231 strain had the highest autolysis rate $(16.48 \%)$ at $\mathrm{pH} 5$ and $3 \% \mathrm{NaCl}$ among all experimental groups. In fact, the autolysis rate of the same strain in PBS buffer was higher than this rate. These results showed that the combined effect of
$\mathrm{pH}$, temperature and $\mathrm{NaCl}$ may reduce the rate of autolysis of LAB strains. Nunez et al. (2011) reported that the $\mathrm{pH}$ of medium was more effective than $\mathrm{NaCl}$ concentration to the extent of the autolysis of $L A B$ strains in such a simultaneous model system. On the other hand, E. durans PFC235 and E. faecium PFC232 strains as well as Lb. plantarum PFC231 may contribute to cheese ripening through autolysis.

Intracellular enzymes of starters used as an adjunct culture are expected to exhibit proteolytic activity as well as high autolytic character for successful ripening of white-brined cheeses. With respect to that, the ability of intracellular proteolytic activity on casein fragmentation was studied after the autolysis of LAB cells. E. faecium PFC232 cell lysate disrupted casein at the end of $24 \mathrm{~h}$ and eventually formed low molecular weight casein fragments in $72 \mathrm{~h}$. The Lb. plantarum PFC231 cell lysate disrupted casein after $24 \mathrm{~h}$ while casein bands disappeared after 48 h (Fig. 4). The cell lysates of E. durans PFC235, Lc. lactis subsp. lactis PFC229 and Lb. helveticus PFC236 strains had no proteolytic activity on casein. Leu. mesenteroides PFC234 and P. acidilactici PFC237 showed high proteolytic activity after $48 \mathrm{~h}$, and there were not any casein fragments after 72 h. Lb. casei PFC230 cell lysate was able to disrupt casein in $72 \mathrm{~h}$. The proteolytic activities of cell lysates of the Lc. lactis subsp. cremoris PFC233 and Lb. rhamnosus PFC238 were first detected at $24 \mathrm{~h}$, and low molecular weight casein fragments remained after $48 \mathrm{~h}$.

The intracellular proteolytic activity of $L b$. plantarum PFC231 strain was high due to the complete degradation of casein at the end of $48 \mathrm{~h}$. Additionally, Leu. mesenteroides PFC234, Lc. lactis subsp. cremoris PFC233, P. acidilactici PFC237 and Lb. rhamnosus PFC238 also showed high caseinolytic activity (Fig. 4). These results indicated that these LAB strains, especially Lb. plantarum PFC231, may degrade casein and thus contribute to cheese ripening by their intracellular proteolytic enzymes after autolysis. In fact, peptidases released as a result of autolysis of cells and existed in cheese matrices have been previously reported to have the ability to degrade proteins into peptides and amino acids, which may have a significant role in the development of cheese aroma (Boutrou et al., 1998; Sheehan et al., 2005; Hannon et al. 2007). 


\section{Conclusions}

In this study, the isolation, identification and characterization of autolytic LAB was examined for the first time on the basis of technological aspects of white-brined cheese production for accelerated ripening. Raw milk was an important source for more autolytic $L A B$ isolates than cheese samples, and the abundant autolytic strains were E. faecium and Lc. lactis in the microflora of raw milk and cheese samples (Fig. 1, Table 1). Furthermore, the autolytic behavior of LAB strains decreased at low $\mathrm{pH}$ values. Although the overall effect of salt concentration on the autolytic activity of $L A B$ strains was insignificant, each strain exhibited a maximum autolytic rate at different salt concentration. The use of glucose as a carbon source increased the autolytic rates of LAB strains significantly; however, the highest activity was found for $L b$. plantarum PFC231 strain in the presence of lactose. The proteolytic activity of the intracellular content of LAB strains should be also considered besides their high autolytic activity. Results indicated that for the autolytic behavior at low temperature, $\mathrm{pH}$ and high salt concentrations, which are influential factors for cheese ripening, Lb. plantarum PFC231 has the potential to be used as an adjunct starter culture in the production of white-brined cheeses. Further studies are needed to test the actual potential of the LAB strains with high autolytic and intracellular proteolytic activity in white-brined cheese production. Moreover, the intracellular proteolytic activity of the selected $L A B$ stains with high autolytic activity should be further studied individual casein fractions in details.

\section{Acknowledgements}

This research was financially supported by the General Directorate of Agricultural Researches and Policies (TAGEM) of the Ministry of Agriculture and Foresty, Turkey (Project Number: TAGEM-13/ AR-GE/11) and the Scientific Research Coordination Unit of Pamukkale University (Project Number: 2014FEBE070). The results and views set out in this publication do not necessarily reflect the official opinion of the Ministry of Agriculture and Foresty, Turkey.

\section{Odabir autolitičkih bakterija mliječne kiseline kao mogućih starter kultura za ubrzavanje zrenja sireva u salamuri}

\section{Sažetak}

Cilj ovog rada bio je odabrati bakterije mliječne kiseline (LAB) koje imaju autolitičku aktivnost, kako bi se upotrebljavale za ubrzavanje procesa zrenja sireva u salamuri. U tu svrhu je iz 34 uzorka sirovog mlijeka te 16 uzoraka sira izolirano 526 mezofilnih i 413 termofilnih sojeva LAB. Primjenom 16SrDNA analize sekvenci i (GTG) $)_{5}$ metode otiska prsta izolirano je ukupno 27 sojeva s autolitičkom aktivnošću koja se kretala između 34 i 54 \%. Pritom su se najdominantnijim autolitičkim vrstama u sirovom mlijeku pokazali Lactococcus lactis i Enterococcus faecium, dok su u siru prevladavali Enterococcus faecium i Lactobacillus casei. Stupanj autolize sojeva LAB rastao je s porastom temperature i pH, dok je opadao pri povišenim koncentracijama $\mathrm{NaCl}$. Nadalje, kod svih sojeva je najveća autoliza zabilježena uz prisutnost glukoze. Međutim, soj Lb. plantarum PFC231 ovdje se izdvajao, pokazujući najveću autolizu u prisutnosti laktoze. Sojevi E. durans PFC235, E. faecium PFC232 i Lb. plantarum PFC231 su pri izloženosti niskom pH i visokoj koncentraciji $\mathrm{NaCl}$ pri $10{ }^{\circ} \mathrm{C}$ pokazivali viši stupanj autolize u odnosu na ostale sojeve. Međutim, samo su sojevi Lb. plantarum PFC231, Leuconostoc mesenteroides PFC234, Lc. lactis subsp. cremoris PFC233, Pediococcus acidilactici PFC237 i Lb. rhamnosus PFC238 pokazali sposobnost unutarstanične hidrolize kazeina. Zaključno, soj Lb. plantarum PFC231 jedini je pokazao potencijal za upotrebu kao starter kultura u proizvodnji sireva u salamuri, budući da ima autolitičku aktivnost pri niskim temperaturama i pH vrijednosti, te visokoj koncentraciji soli, a pokazao je i sposobnost unutarstanične hidrolize kazeina.

Ključne riječi: bakterije mliječne kiseline, Lactobacillus plantarum, autoliza, sir u salamuri, zrenje sira 
1. Amaral, D.M.F., Silva, L.F., Casarotti, S.N., Nascimento, L.C.S., Penna, A.L.B. (2017): Enterococcus faecium and Enterococcus durans isolated from cheese: Survival in the presence of medications under simulated gastrointestinal conditions and adhesion properties. Journal Dairy Science 100 (2), 933-949. https://doi.org/10.3168/jds.2016-11513.

2. Aspri, M., O'Connor, P.M., Field, D., Cotter, P.D., Ross, P., Hill, C., Papademas, P. (2017): Application of bacteriocinproducing Enterococcus faecium isolated from donkey milk, in the bio-control of Listeria monocytogenes in fresh whey cheese. International Dairy Journal 73, 1-9. https://doi.org/10.1016/j.idairyj.2017.04.008

3. Beresford, T.P., Fitzsimons, N.A., Brennan, N.L., Cogan, T.M. (2001): Recent advances in cheese microbiology. International Dairy Journal 11, 259-274.

4. Boutrou, R., Sepulchre, A., Pitel, G., Durier, C., Vassal, L., Gripon, J.C., Monnet, V. (1998): Lactococcal lysis and curd proteolysis: Two predictable events important for the development of cheese flavor. International Dairy Journal 8 , 609-616. https://doi.org/10.1016/S0958-6946(98)00090-9

5. Chapot-Chartier, M., Kulakauskas, S. (2014): Cell wall structure and functions in lactic acid bacteria. Microbial Cell Factories 13, 1-23. https://doi.org/10.1186/1475-2859-13-S1-S9

6. Collins, Y.F., McSweeney, P.L.H., Wilkinson, M.G. (2003): Evidence of a relationship between autolysis of starter bacteria and lipolysis in Cheddar cheese during ripening. Journal of Dairy Research 70, 105-113. https://doi.org/10.1017/S0022029902005915

7. Çıbık, R., Chapot-Chartier, P. (2004): Characterization of autolytic enzymes in Lactobacillus pentosus. Letters in Applied Microbiology 38, 459-463. https://doi.org/10.1111/j.1472-765X.2004.01516.x

8. Dako, E., El-Soda, M., Vuillemard, J.C., Simard, R.E. (1995): Autolytic properties and aminopeptidase activities of lactic acid bacteria. Food Research International 28, 503-509.

9. De Vuyst, L., Leroy, F. (2007): Bacteriocins from lactic acid bacteria: Production, purification, and food applications. Journal Molecular Microbiology Biotechnology 13, 194-199. https://doi.org/10.1159/000104752

10. Fox, P.F., McSweeney, P.L.H. (1996): Proteolysis in cheese during ripening. Food Review International 12(4), 457-509. https://doi.org/10.1080/87559129609541091

11. Hannon, J.A., Kilcawleya, K.N., Wilkinson, M.G., Delahunty, C.M., Beresford, T.P. (2007): Flavor precursor development in Cheddar cheese due to lactococcal starters and the presence and lysis of Lactobacillus helveticus. International. Dairy Journal 17, 316-327. https://doi.org/10.1016/j.idairyj.2006.03.001

12. Huard, C., Miranda, G., Redko, Y., Wessner, F., Foster, S.J., Chapot-Chartier, M.P. (2004): Analysis of the peptidoglycan hydrolase complement of Lactococcus lactis: Identification of a third N-acetylglucosaminidase, AcmC. Applied Environmental Microbiology, 70, 3493-3499. https://doi.org/10.1128/AEM.70.6.3493-3499.2004
13. Gursoy, O., Kesenkas, H., Yilmaz, Y. (2013): White Cheese. In: Hand Book of Cheese in Health: Production, Nutrition and Medical Sciences. Human Health Handbooks No: 6 , Edited by V.R. Preedy, R.R. Watson, V.B Patel, (ISBN: 97890-8686-211-5), Wageningen Academic Publishers, The Netherlands, pp. 183-191. https://doi.org/10.3920/978-90-8686-766-0_12

14. Karabey, B., Eroglu, D., Vural, C., Ozdemir, G., Yerlikaya, O., Kinik, O. (2018): Determination of the microbial flora in traditional İzmir Tulum cheeses by Denaturing Gradient Gel Electrophoresis. Journal of Food Science Technology 55(3), 956-963. https://doi.org/10.1007/s13197-017-3003-z.

15. Lazzi, C., Povolo, M., Locci, F., Bernini, V., Neviani, E., Gatti, M. (2016): Can the development and autolysis of lactic acid bacteria influence the cheese volatile fraction? The case of Grana Padano. International Journal of Food Microbiology 233, 20-8. https://doi.org/10.1016/j.ijfoodmicro.2016.06.009.

16. Lortal, S., Chapot-Chartier, M.P., (2005): Role, mechanisms and control of lactic acid bacteria lysis in cheese. International Dairy Journal 15, 857-871. https://doi.org/10.1016/j.idairyj.2004.08.024

17. McSweeney, P.L.H. (2004): Biochemistry of cheese ripening. International Journal of Dairy Technology 57, 127-144. https://doi.org/10.1111/j.1471-0307.2004.00147.x

18. Meng, Z., Zhang, L., Xin, L., Lin, K., Yi, H., Han, X. (2018): Technological characterization of Lactobacillus in semihard artisanal goat cheeses from different Mediterranean areas for potential use as nonstarter lactic acid bacteria. Journal of Dairy Science 101(4), 2887-2896. https://doi.org/10.3168/jds.2017-14003.

19. Nunez, J.R., Medrano, R.R., Moorillon, G.V.N., Mendez, N.G. (2011): Effect of pH and salt gradient on the autolysis of Lactococcus lactis strains. Brazilian Journal of Microbiology 42, 1495-1499. http://doi.org/10.1590/S1517-83822011000400036

20. Ogier, J.C., Serror, P. (2008): Safety assessment of dairy microorganisms: The Enterococcus genus. International Journal of Food Microbiology 126(3), 291-301. https://doi.org/10.1016/j.jifoodmicro.2007.08.026

21. Ostlie, H.M., Vegarud, G., Langsrud, T (1995): Autolysis of lactococci: detection of lytic enzymes by polyacrylamide gel electrophoresis and characterization in buffer systems. Applied Environmental Microbiology 10, 3598-3603.

22. Piraino, P., Zotta, T., Ricciardi, A., McSweeney, P., Parente, E. (2008): Acid production, proteolysis, autolytic and inhibitory properties of lactic acid bacteria isolated from Pasta Filata Cheeses: A multivariate screening study. International Dairy Journal 18, 81-92. https://doi:10.1016/j.idairyj.2007.06.002

23. Rolain, T., Bernard, E., Courtin, P., Bron, P.A., Kleerebezem, M., Chapot-Chartier, M.P., Hols, P. (2012): Identification of key peptidoglycan hydrolases for morphogenesis, autolysis, and peptidoglycan composition of Lactobacillus plantarum WCFS1. Microbial Cell Factories 11, 137-142. https://doi.org/10.1186/1475-2859-11-137 
24. Schägger, H., von Jagow, G. (1987): Tricine-sodium dodecyl sulfate-polyacrylamide gel electrophoresis for the separation of proteins in the range from 1 to $100 \mathrm{kDa}$. Analytical Biochemistry 166, 368-379. https://doi.org/10.1016/0003-2697(87)90587-2

25. Sheehan, A., O'Loughlin, C., O'Cuinn, G., Fitzgerald, R. J., Wilkinson, M. G. (2005): Cheddar cheese cooking temperature induces differential lactococcal cell permeabilization and autolytic responses as detected by flow cytometry: implications for intracellular enzyme accessibility. Journal of Applied Microbiology 99, 1007-1018. https://doi.org/10.1111/j.1365-2672.2005.02718.x

26. Shockman, G.D., Daneo-Moore, L., Kariyama, R., Massidda, O. (1996): Bacterial walls, peptidoglycan hydrolases, autolysins and autolysis. Microbial Drug Resistant, 2, 95-98.

27. Smith, T.J., Blackman, S.A., Foster, S.J. 2000. Autolysins of Bacillus subtilis: multiple enzymes with multiple functions. Microbiology 146, 249-262.

https://doi.org/10.1099/00221287-146-2-249
28. Sousa, M.J., Ardö, Y., McSweeney, P.L.H., (2001): Advances in the study of proteolysis during cheese ripening. International Dairy Journal 11, 327-345. https://doi.org/10.1016/S0958-6946(01)00062-0

29. Vegarud, G., Castberg, H.B. and Langsrud, T. (1983): Autolysis of group N streptococci: effects of media composition, modifications and temperature, Journal Dairy Science, 66, 2294-2302.

30. Wilkinson, M.G., Kilcawley, K.N. (2005): Mechanisms of incorporation and release of enzymes into cheese during ripening. International Dairy Journal 15, 817-830. https://doi.org/10.1016/j.idairyj.2004.08.021

31. Zuo, F.L., Feng, X.J., Chen, L.L., Chen, S.W. (2014): Identification and partial characterization of lactic acid bacteria isolated from traditional dairy products produced by herders in the western Tianshan Mountains of China. Letters in Applied. Microbiology, 59(5), 549-556. https://doi.org/10.1111/lam.12313 